\title{
Thinking through the climate change challenge
}

Link to publication record in Manchester Research Explorer

\section{Citation for published version (APA):}

Hahn, R., \& Ulph, A. (2011). Thinking through the climate change challenge. Vox EU.

\section{Published in:}

Vox EU

\section{Citing this paper}

Please note that where the full-text provided on Manchester Research Explorer is the Author Accepted Manuscript or Proof version this may differ from the final Published version. If citing, it is advised that you check and use the publisher's definitive version.

\section{General rights}

Copyright and moral rights for the publications made accessible in the Research Explorer are retained by the authors and/or other copyright owners and it is a condition of accessing publications that users recognise and abide by the legal requirements associated with these rights.

\section{Takedown policy}

If you believe that this document breaches copyright please refer to the University of Manchester's Takedown Procedures [http://man.ac.uk/04Y6Bo] or contact uml.scholarlycommunications@manchester.ac.uk providing relevant details, so we can investigate your claim.

\section{OPEN ACCESS}


Sustainable Consumption

Institute

\title{
Thinking through the climate change challenge
}

\author{
January 2011
}

Sustainable Consumption Institute

The University of Manchester

188 Waterloo Place

Oxford Road

Manchester M13 9PL

Tel: +44(0) 1612754030 


\title{
Thinking through the climate change challenge
}

\author{
An open letter ${ }^{*}$
}

January 2011

David Anthoff, University of California, Berkeley

Elizabeth Baldwin, University of Oxford

Scott Barrett, Columbia University

Linda Cohen, University of California, Irvine

Diane Coyle, Enlightenment Economics

Partha Dasgupta, University of Cambridge

Simon Dietz, London School of Economics and Political Science

David J Frame, University of Oxford

Robert Hahn, The University of Manchester

James K Hammitt, Toulouse School of Economics

Geoffrey Heal, Columbia University

Cameron Hepburn, University of Oxford

Michael Hoel, University of Oslo

Charles D Kolstad, University of California, Santa Barbara

Andreas Lange, University of Hamburg

Robert Mendelsohn, Yale University

Karine Nyborg, University of Oslo

Ian WH Parry, Resources for the Future

Peter Passell, Milken Institute

Kenneth Richards, Indiana University

Robert Ritz, University of Cambridge

Thomas C Schelling, University of Maryland

Massimo Tavoni, FEEM (Fondazione Eni Enrico Mattei)

Alistair Ulph, The University of Manchester

Herman RJ Vollebergh, Tilburg University Sustainability Centre (TSC)

Anastasios Xepapadeas, Athens University of Economics and Business

\footnotetext{
* This article was prepared following a conference in honour of Nobel Laureate Tom Schelling held at the Sustainable Consumption Institute at the University of Manchester on 21-22 October 2010. The more detailed findings of this conference will be published in Hahn, R and A Ulph (eds.) (forthcoming), Climate Change and Common Sense: Essays in Honour of Tom Schelling, Oxford University Press. The views expressed in this paper reflect those of the authors and do not necessarily reflect those of the institutions with which they are affiliated. ( 2011 by the authors. All rights reserved.
} 


\section{Thinking through the climate change challenge}

In October 2010, a group of leading thinkers on environmental policy met at the Sustainable Consumption Institute at the University of Manchester for a conference in honour of Nobel Laureate Tom Schelling. This column presents a 10-point guideline for climate change policy coauthored by 26 attendees that focuses on designing policies that are credible, easily monitored, and easily enforced.

Late last year, a group of leading thinkers on environmental policy met at the Sustainable Consumption Institute at the University of Manchester for a conference in honour of Nobel economics Laureate Tom Schelling. At the event we formulated guidance for policymakers which draws on work that Schelling (perhaps best known for his pioneering efforts on nuclear deterrence) has done on climate change. The analysis here relies on his concept of identifying "focal points" on which agreements can be based, and his emphasis on designing policies that are credible as well as easily monitored and enforced.

\section{Problem overview}

Global climate change is one of the greatest problems facing mankind that requires collective action in order to be solved. Although there would be substantial long-term gains to all societies from working together to limit greenhouse gas emissions, many countries lack strong incentives to reduce their own emissions over the short term. It is therefore unlikely that an economically efficient outcome could be achieved in the best of circumstances.

What's more, climate negotiations such as the meetings in Copenhagen and Cancun are likely to fail to reach an effective agreement on reducing greenhouse gas emissions. The terms of the negotiations thus need to be radically changed.

The international community has arrived at a focal point (in Schelling's terms) of limiting global temperature increases to $2 \mathrm{oC}$. But without agreement on enforceable action to achieve the target, this will have little impact. We therefore offer ten concrete points for policy makers. 


\section{Guidance for decision makers}

1. Economic analysis suggests that governments have significantly underinvested in mitigation relative to the level of effort that would be economically efficient from a global perspective.

2. All realistic options for addressing climate change should be seriously considered. These include controlling greenhouse gas emissions, removing carbon dioxide from the atmosphere, adaptation to change, and geo-engineering.

3. International agreements are needed because coordination would help ensure that policies achieve climate policy goals at minimum cost to society. But this does not imply that agreements must cover all countries and all sectors. Nor does it imply that action on the part of individual states must wait until there is an international accord.

4. New approaches that pass a benefit-cost test should be tried. While comprehensive approaches are appealing in principle, they face serious political hurdles. An alternative is to address specific greenhouse gases and sectors in separate agreements. There could, for example, be an agreement on maintaining forests and planting trees, and another on regulating carbon dioxide emissions from fossil fuel use. A primary focus of negotiations should be on the practical measures needed to monitor and enforce whatever is agreed. To date, enforcement of climate agreements has been weak.

5. Putting a price on greenhouse gas emissions (by taxing them or limiting aggregate output with a cap-and-trade mechanism) would be desirable because it would help to get consumers, businesses, and government to account for the full social cost of their behaviour. Many countries already have explicit or implicit prices on greenhouse gas emissions, which will help to reduce the cost of greenhouse gas reductions in the future. A potential issue complicating pricing policies is that they can create large revenue streams. Such revenue should be used productively - for example, by reducing other taxes that distort economic activity.

6. Climate stabilisation requires that net carbon dioxide emissions eventually decline significantly. Achieving that goal will require a technological revolution. This is one reason why research and development in energy technologies should be a priority, though policies should be carefully designed to ensure innovative efforts are socially productive.

7. Research and development is also needed in technologies for removing carbon dioxide from the atmosphere and for managing solar radiation, even though these technologies may not be deployed for decades, if ever. Efforts should begin now to develop strong 
norms and governance arrangements for determining the appropriate use of geoengineering technologies.

8. Businesses need appropriate incentives for innovation, investment and behavioural change. Thus, policy commitments for $\mathrm{R} \& \mathrm{D}$ and pricing greenhouse gas emissions should strive to be credible and reasonably stable over long periods.

9. The incentives for consumers, firms, and governments to adapt to climate change are strong because they will bear most of the costs if they do not adapt. The poorest countries, however, are least able to adapt. The industrialised countries should help them. The most effective means of providing assistance requires careful study. It may include a portfolio of efforts targeted more toward economic development than to climate adaptation.

10. There are great uncertainties in how best to manage the various components of the climate change problem. These uncertainties should be acknowledged by adopting a flexible approach to decision making that responds to new knowledge about climate change. Uncertainty should not, however, be used as a rationale for inaction.

Instead of negotiating about targets and timetables that are strongly opposed by key parties and that cannot be easily enforced, policymakers should focus on concrete alternatives that can be monitored and enforced. Continued efforts to reach a comprehensive agreement that lack these characteristics offer little prospect of success. 